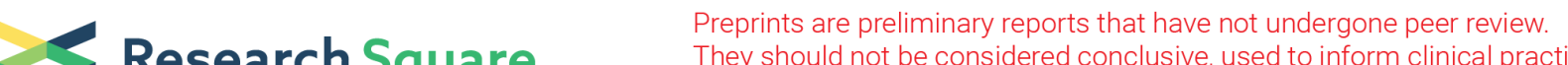 $\begin{array}{ll}\text { Research Square } & \text { They should not be considered conclusive, used to inform clinical practice, } \\ \text { or referenced by the media as validated information. }\end{array}$
}

\section{Bentonite Clay Mixed With Different N Sources Have Variable Effect on Nitrate Leaching From Sandy Soil}

\section{Zahid Hussain}

Yunnan Research Academy of Eco-Environmental Sciences

Cheng Tang ( $\nabla 1290992119 @ q q . c o m$ )

Yunnan Research Academy of Eco-Environmental Sciences

Muhammad Irshad

COMSATS University Islamabad (CUI)

\section{Riaz A. Khattak}

The Brains Institute

Chen Yao

Yunnan Infrastructure Investment Co. Ltd

\section{Di Song}

Yunnan Research Academy of Eco-Environmental Sciences

Muhammad Mohiuddin

Kohsar University

\section{Research Article}

Keywords: bentonite, nitrate leaching, $\mathrm{N}$ sources, sandy soil

Posted Date: November 30th, 2021

DOI: https://doi.org/10.21203/rs.3.rs-1081687/v1

License: (c) (i) This work is licensed under a Creative Commons Attribution 4.0 International License.

Read Full License 


\section{Abstract}

Nitrate $\left(\mathrm{NO}_{3}\right)$ leaching from soils results in lower soil fertility, reduced crop productivity and groundwater pollution. The present study determined $\mathrm{NO}_{3}$ leaching from bentonite $[0,2$ and $4 \%(\mathrm{~m} / \mathrm{m})]$ treated sandy soil, under three $\mathrm{N}$ sources (calcium nitrate $\left[\mathrm{Ca}\left(\mathrm{NO}_{3}\right)_{2}\right]$, ammonium chloride $\left[\mathrm{NH}_{4} \mathrm{Cl}\right]$, urea $\left[\mathrm{CO}\left(\mathrm{NH}_{2}\right)_{2}\right] @$ $300 \mathrm{~kg} \mathrm{~N} \mathrm{ha}^{-1}$ ) with a leaching fraction of 0.3-0.4. Bentonite markedly reduced $\mathrm{NO}_{3}$ release in leachate, while $4 \%$ bentonite retained higher $\mathrm{NO}_{3}$ in soil. The $\mathrm{NO}_{3}$ leaching varied with $\mathrm{N}$ sources as $\mathrm{Ca}\left(\mathrm{NO}_{3}\right)_{2}>\mathrm{NH} \mathrm{H}_{4} \mathrm{Cl}>\left(\mathrm{CO}\left(\mathrm{NH}_{2}\right)_{2}\right.$. This study indicated that soil amendment with bentonite could efficiently mitigate $\mathrm{NO}_{3}$ leaching from soil and hence prevent $\mathrm{N}$ fertilizer losses and groundwater pollution.

\section{Highlights}

- Sandy soils are more prone to nutrient leaching

- Application of $\mathrm{N}$ sources enhanced $\mathrm{NO}_{3}$ leaching from the sandy soil

- $\mathrm{NO}_{3}$ leaching reduces soil fertility and causes groundwater pollution

- Bentonite amendment significantly reduced $\mathrm{NO}_{3}$ leaching from sandy soil

- The $\mathrm{NO}_{3}$ leaching decreased with $\mathrm{N}$ sources in the order as $\mathrm{Ca}\left(\mathrm{NO}_{3}\right)_{2}>\mathrm{NH}_{4} \mathrm{Cl}>\mathrm{CO}\left(\mathrm{NH}_{2}\right)_{2}$

\section{Introduction}

Intensive agriculture requires increased fertilizer inputs to maximize crop production for meeting the food demands of growing populations. Food demand and fertilizers use have been forecasted to double or triple by $2050^{[1]}$. Agricultural use of $\mathrm{N}$ fertilizers is causing $\mathrm{N}$ leakage from the cropped fields into the water bodies and atmosphere. This practice increased nutrient losses and resulted in tremendous nitrogen $(\mathrm{N})$ pollution with subsequent ecological damage. There is a general consensus that nitrate leaching from soils has caused substantial environmental threats. The primary source of $\mathrm{N}$ pollution is mainly related to $\mathrm{N}$ fertilizers. Developing an effective technology to retain nutrients in soils is imperative to prevent $\mathrm{NO}_{3}$ leaching from soils. Soil amendments have been considered as management practice to reduce $\mathrm{NO}_{3}$ losses from sandy soils ${ }^{[2]}$. The bentonite is an alumina-siliceous clay material, which has not been utilized to control $\mathrm{NO}_{3}$ leaching.

Soil $\mathrm{NO}_{3}$ is originated from both organic and organic $\mathrm{N}$. Leaching and drainage studies found that $\mathrm{NO}_{3}$ is the major form of $\mathrm{N}$ occurred in the soil water ${ }^{[3][4]}$. The $\mathrm{NO}_{3}$ leaching from soils adversely affects agriculture and the environment. The deterioration of water quality is considered as a major environmental issue ${ }^{[5]}$. The production and use of $\mathrm{N}$ fertilizers are responsible for the environmental problems. With the higher nitrate levels, there can be unfavorable biological consequences for the organisms, which occur relatively in groundwater. Elevated $\mathrm{N}$ contents have altered the natural aquatic dynamics of flora and fauna and exacerbated the process of eutrophication ${ }^{[6]}$. Since $\mathrm{N}$ pollution of groundwater is due to the N-rich fertilizers, therefore, nitrate leaching and runoff into surface water 
ecosystem may cause algal blooms and eutrophication and pose associated health risk. The increasing potential of contamination of water resources is linked with the inefficient management of $\mathrm{N}$ fertilizer when compared with the natural systems ${ }^{[7][8][9]}$. The United States Environmental Protection Agency set the standard for drinking water and health advisory level of $10 \mathrm{mg} \mathrm{L}^{-1}$ nitrate based on the human health risks ${ }^{[10]}$. Higher nitrate consumption has been affiliated with various illnesses, e.g., methemoglobinemia has been proven due to ingestion of over nitrate concentrations in water ${ }^{[10]}$. It is, therefore, imperative to mitigate the nutrient losses, especially $\mathrm{NO}_{3}$ leaching from soil to reduce health risk caused by water contamination.

A number of factors including plant characteristics, seasonal and climatic changes, and soil properties govern $\mathrm{NO}_{3}$ leaching from soils ${ }^{[11]}$. The specific factors include soil texture, soil $\mathrm{N}$ concentration, amount of applied N, type of fertilizer, precipitation amount and intensity, soil water holding capacity, types of crops, rooting length and $\mathrm{N}$ demand of next crop ${ }^{[12]}$. Leaching of $\mathrm{NO}_{3}-\mathrm{N}$ is more common than leaching of $\mathrm{NH}_{4}-\mathrm{N}$ since both $\mathrm{NO}_{3}-\mathrm{N}$ and soil are negatively charged. Over application or un-timely application of animal manures or commercial $\mathrm{N}$ fertilizers result in nutrient imbalance in soils which lead to increased $\mathrm{N}$ leaching rates, especially of $\mathrm{NO}_{3}$, into groundwater ${ }^{[13]}$. Sandy soils, due to low water holding capacity, allow $\mathrm{NO}_{3}$ to leach into groundwater faster than the soils having five textures, such as clay loams ${ }^{[12]}$.

Clays are hydrous aluminosilicates with fine colloids of $<2 \mathrm{~mm}$ of soils. They are composed of finegrained clays minerals and crystals such as quartz, carbonates and oxides ${ }^{[14]}$. Clays are considered to retain contaminants by anion and cation exchange processes and prevent leaching into groundwaters. Due to effective adsorption capacities, bentonite clay has been used for multiple purposes. Bentonite is also used to remove dyes, radioactive waste, purification of viral RNA and of waste water ${ }^{[15][16][17]}$. Bentonite application as amendment enhanced soil fertility by increased soil carbon and potassium ${ }^{[18]}$, while improved water holding capacity of sandy soils under drought stress ${ }^{[19]}$. Bentonite application to sandy acidic soil improved soil fertility by increasing availability of macro-nutrient to plants ${ }^{[20]}$. Clay amended sandy soil significantly reduced $\mathrm{N}$ and $\mathrm{P}$ leaching ${ }^{[21]}$. Leaching of $\mathrm{NH}_{4}-\mathrm{N}$ was reduced by $70 \%$ from a mixture of biochar, urea and bentonite plus sepiolite clay ${ }^{[22]}$. However, it is still unclear that how the type of fertilizer and application of bentonite clay to soils can mitigate $\mathrm{NO}_{3}$ leaching.

A reduction in the $\mathrm{NO}_{3}$ leaching was expected when clay material was applied to the soil. Reports evaluating the interactive effects of bentonite material and $\mathrm{N}$ sources on the reduction of $\mathrm{NO}_{3}$ leaching from sandy soils are scanty. Therefore, the present study aimed to investigate the influence of bentonite on $\mathrm{NO}_{3}$ leachability from a sandy soil after application of three $\mathrm{N}$ sources.

\section{Materials And Methods}

A leaching experiment was conducted in Soil Science Laboratory at COMSATS University Islamabad, Abbottabad Campus, Pakistan. Locally collected sandy soil samples were utilized for the experiment. Soil 
samples were air-dried and strained through $2 \mathrm{~mm}$ sieve. The soil was tested for $\mathrm{pH}$ and electrical conductivity (EC) in 1:5 (w/v) soil-water suspensions by pH meter and EC meter, respectively ${ }^{[23]}$. The soil was saturated for overnight, weighed and then the water holding capacity (WHC) of the soil was calculating by the difference in the weight of soil. Leaching fraction was calculated by dividing drained water over applied water.

The study was aimed to evaluate nitrate leaching from sandy soil using a clay material. For this purpose, the bentonite material was commercially purchased and then air-dried. The air-dried clay was applied at the rate of 0,2 and $4 \%$ to the sandy soil packed in a PVC tube (size: length $0.50 \mathrm{~m}$, dia $0.15 \mathrm{~m}$ ). Four treatments of nitrogen $(\mathrm{N})$ fertilizers namely calcium nitrate $\left[\mathrm{Ca}\left(\mathrm{NO}_{3}\right)_{2}\right]$, ammonium chloride $\left[\mathrm{NH}_{4} \mathrm{Cl}\right]$, urea $\left[\mathrm{CO}\left(\mathrm{NH}_{2}\right)_{2}\right]$ and control treatment (no fertilizer) were applied to soil. This experiment had two factors (i.e., three bentonite application rates and four fertilizer treatments) with a total of twelve treatments along with three replications. Based on 2.0 million $\mathrm{kg}$ soil per plow layer, each fertilizer was applied at the rate of $300 \mathrm{~kg} \mathrm{~N} \mathrm{ha}^{-1}$. Water was applied at leaching fraction of 0.3 0.4. Leachate was collected within $24 \mathrm{~h}$ after each water application and then transferred to the laboratory for $\mathrm{NO}_{3}$ analysis. The amount of water leached out from treated column was recorded. The bottles used for collecting leachate were erected on the floor and connected to the column. The $\mathrm{NO}_{3}$ was determined at each five leaching events, that is, $1 \mathrm{st}$, 2nd, 4th, 6th and 10th day. The soil was sampled in two layers $(0-25$ and $25-50 \mathrm{~cm})$ from the PVC pipes and was thoroughly mixed. A $10 \mathrm{~g}$ soil sample was shaken in $100 \mathrm{~mL}$ distilled water for $1 \mathrm{~h}$ and then the suspension was filtered. Moisture content in the soil samples was adjusted by oven drying few grams of soil. In filtrate, nitrate was determined by UV spectrophotometer at $220 \mathrm{~nm}^{[24]}$. Data were statistically analyzed by Statview software ${ }^{[25]}$. The three-way analysis of variance (ANOVA) was performed on Sigmaplot, whereas N sources (3 levels), bentonite (3 levels) and leaching events in days (5 levels) were taken as three factors. A post hoc Tukey test was also performed to determine the significant difference between the levels of factors.

\section{Results}

\subsection{Pre-experiment chemical analysis}

Bentonite clay, soil and water were analyzed for chemical properties before experiment, which are presented in Table 1. Analysis revealed that soil had highest $\mathrm{NO}_{3}$ concentrations, compared to bentonite clay. The tap water had meager concentrations of $\mathrm{NO}_{3}$. The electrical conductivity $(\mathrm{EC})$ of bentonite was highest compared to soil and water samples, but still it fell below the category of non-saline (EC $<4 \mathrm{dS}$ $\left.\mathrm{m}^{-1}\right)$. However, the $\mathrm{pH}$ of bentonite was lower $(\mathrm{pH}<7)$ making it more acidic as compared to soil and water. 
Table 1

Nitrate, electrical conductivity (EC) and pH of bentonite clay material, soil and tap water

\begin{tabular}{|llll|}
\hline Material & Nitrate & $\mathrm{EC}\left(\mathrm{mS} \mathrm{m}^{-1}\right)$ & $\mathrm{pH}$ \\
\hline Bentonite $\left(\mathrm{mg} \mathrm{kg}^{-1}\right)$ & 23.5 & 126.7 & 5.7 \\
\hline Soil $\left(\mathrm{mg} \mathrm{kg}^{-1}\right)$ & 34.4 & 87.8 & 7.8 \\
\hline Tap water $\left(\mathrm{mg} \mathrm{L}^{-1}\right)$ & 7.8 & 37.5 & 7.2 \\
\hline
\end{tabular}

\subsection{Effect of bentonite and $\mathrm{N}$ sources on $\mathrm{NO}_{3}$ leaching}

Impact of bentonite clay mixed with different $\mathrm{N}$ sources on NO3 leaching is illustrated in Fig. 1. Results showed $\mathrm{NO}_{3}$ concentration decreased by 12 to $19 \%$ in the leachate, irrespective of the source of $\mathrm{N}$ with increasing bentonite rates. The highest reduction (19\%) in $\mathrm{NO}_{3}$ leaching was recorded with $\mathrm{Ca}\left(\mathrm{NO}_{3}\right)_{2}$ with $4 \%$ bentonite as compared with $\mathrm{CO}\left(\mathrm{NH}_{2}\right)_{2}$ and $\mathrm{NH}_{4} \mathrm{Cl}$ at similar bentonite rates. At early stages of leaching, the leachate showed higher concentrations of $\mathrm{NO}_{3}$ in leachate with both $\mathrm{NH}_{4} \mathrm{Cl}$ and $\mathrm{Ca}\left(\mathrm{NO}_{3}\right)_{2}$, but leaching of $\mathrm{NO}_{3}$ increased with urea sources at later leaching stages (Fig. 2). Fig. 3. showed that $\mathrm{NO}_{3}$ leaching was higher from urea treated soil as compared to $\mathrm{NH}_{4} \mathrm{Cl}$ and $\mathrm{Ca}\left(\mathrm{NO}_{3}\right)_{2}$ treaded soil. The incubation of soil with bentonite reduced $\mathrm{NO}_{3}$ content by $7 \%, 20 \%$ and $8 \%$ with $\mathrm{Ca}\left(\mathrm{NO}_{3}\right)_{2}, \mathrm{NH}_{4} \mathrm{Cl}$ and $\mathrm{CO}\left(\mathrm{NH}_{2}\right)_{2}$ treated soil, respectively (Fig. 4).

\section{Statistical Analysis}

A three-way analysis of variance (ANOVA) was performed on $\mathrm{NO}_{3}$ leaching with $3 \mathrm{~N}$ sources, 3 levels of bentonite and 5 events (Table 2). Analysis showed that there was significant difference $(P<0.001)$ within $\mathrm{N}$ sources, bentonite levels and leaching events (days). There was statistically significant $(P<0.01)$ interaction among all the factors. The Tukey test revealed significant $(P<0.05)$ difference between $0 \%$ and $2 \%$, and $0 \%$ and $4 \%$ bentonite with all $\mathrm{N}$ sources on $\mathrm{NO}_{3}$ leaching, but the difference was not significant between $2 \%$ and $4 \%$ bentonite with all $\mathrm{N}$ sources. 
Table 2

Summary ANOVA on effect of bentonite and N sources on NO3 leaching at different leaching events

\begin{tabular}{|llllll|}
\hline Source of Variation & DF & SS & MS & F & P \\
\hline N sources (N) & 2 & 2943336.133 & 1471668.067 & 14453.309 & $<0.001$ \\
\hline Bentonite levels (B) & 2 & 74157.911 & 37078.956 & 364.154 & $<0.001$ \\
\hline Leaching Events/Day (D) & 4 & 282061.822 & 70515.456 & 692.535 & $<0.001$ \\
\hline N x B & 4 & 11270.489 & 2817.622 & 27.672 & $<0.001$ \\
N x D & 8 & 589355.422 & 73669.428 & 723.510 & $<0.001$ \\
B x D & 8 & 15955.644 & 1994.456 & 19.588 & $<0.001$ \\
\hline N x B x D & 16 & 24125.511 & 1507.844 & 14.809 & $<0.001$ \\
\hline Residual & 90 & 9164.000 & 101.822 & & \\
\hline Total & 134 & 3949426.933 & 29473.335 & & \\
\hline
\end{tabular}

\section{Discussion}

Results showed that irrespective of the source of $\mathrm{N}$, the $\mathrm{NO}_{3}$ leaching consistently decreased with increasing bentonite application showing the sequences of fertilizer type as: $\mathrm{Ca}\left(\mathrm{NO}_{3}\right)_{2}>\mathrm{NH}_{4} \mathrm{Cl}>$ $\mathrm{CO}\left(\mathrm{NH}_{2}\right)_{2}$ (Fig. 1). Form of $\mathrm{N}$ leached from the soil columns was closely related to the type of fertilizer applied to the soil ${ }^{[26]}$. The $\mathrm{NO}_{3}$ fertilizers appeared to be more sensitive to the leaching, especially in sandy soils ${ }^{[27]}$ and also to the denitrification ${ }^{[28]}$ as compared to urea or ammonium fertilizers. Also, $\mathrm{NO}_{3}$ leaching is substantially higher in free-drained soils ${ }^{[29]}$, such as sandy soil with macropores used in the present study.

Application of bentonite decreased $\mathrm{NO}_{3}$ leaching, regardless to the rate of application. The $\left[\mathrm{NO}_{3}\right]$ decreased with increasing bentonite treatments level. Whereby higher $\mathrm{NO}_{3}$ concentration was observed in $\mathrm{NO}_{3}$ and $\mathrm{NH}_{4}$ containing fertilizers during the initial leaching (Fig. 2). Urea form of $\mathrm{N}$ showed consistent increases in $\mathrm{NO}_{3}$ concentrations in water collected in later leaching stages (Fig. 2). This could be associated with increased nitrification process in soils under unsaturated conditions ${ }^{[30]}$, which might have resulted in increased $\mathrm{NO}_{3}$ leaching at later stages. Accumulation of $\mathrm{NO}_{3}$ was more in the soil sampled from the lower layer of the column after a leaching process, showing the sequence as $\mathrm{CO}\left(\mathrm{NH}_{2}\right)_{2}$ $>\mathrm{NH}_{4} \mathrm{Cl}>\mathrm{Ca}\left(\mathrm{NO}_{3}\right)_{2}$.

The amount of residual $\mathrm{NO}_{3}$ in soil was conversely related to the amount of $\mathrm{NO}_{3}$ in the leachates (Fig. 3). An enhanced application of bentonite significantly retained $\mathrm{NO}_{3}$ in the soil columns. A higher amount of $\mathrm{NO}_{3}$ was retained in the soil amended with $4 \%$ bentonite. The application of bentonite clay enhanced soil 
moisture and improved macro-aggregate development ${ }^{[31]}$ which improved soil quality through structural development, by increased exchange of anions and cations ${ }^{[32]}$ and helped in reduced leaching while promoting nutrient retention ${ }^{[33]}$.

Bentonite amendment was effective in reducing the leachability of $\mathrm{Cu}$ from soil ${ }^{[34]}$. Enrichment of sandy soils with bentonite increased the porosity and altered the pore-size distribution ${ }^{[35]}$. The interactions of bentonite with biochar and urea improved soil properties by diffusing soil moisture which controlled the mobility of nutrients within soils ${ }^{[36]}$, thus with high water retaining capacity, increased exchange capacity, swelling, thermal stability and slow-releasing characteristics, bentonite offers valuable solution to reduced nutrient leaching from loose soils.

Higher quantity of $\mathrm{NO}_{3}$ was released in urea treated soil followed by ammonium and nitrate containing fertilizers (Fig. 3). This could be attributed to the transformation of $\mathrm{NO}_{3}$ in urea contained soil after few days of incubation. Across all $\mathrm{N}$ sources, the application of bentonite (4\%) markedly limited the release of $\mathrm{NO}_{3}$. After incubation, bentonite contents reduced the magnitude of $\mathrm{NO}_{3}$ among fertilizers as follow: $7 \%$ in $\mathrm{Ca}\left(\mathrm{NO}_{3}\right)_{2}, 20 \%$ in $\mathrm{NH}_{4} \mathrm{Cl}$ and $8 \%$ in urea treated soil (Fig. 4). The soil having negatively charged sites attracts more the positively charged $\mathrm{NH}_{4}$ as compared to negatively charged $\mathrm{NO}_{3}$, and therefore the $\mathrm{NH}_{4}$ has been considered to be a less mobile in soils, than $\mathrm{NO}_{3}{ }^{[29][37][38]}$.

The effect of bentonite on the leachability of $\mathrm{NO}_{3}$ varied with different $\mathrm{N}$ fertilizers. The $\mathrm{NO}_{3}$ leaching consistently decreased with increasing bentonite application showing the sequences of fertilizer type as: $\mathrm{Ca}\left(\mathrm{NO}_{3}\right)_{2}>\mathrm{NH}_{4} \mathrm{Cl}>\mathrm{CO}\left(\mathrm{NH}_{2}\right)_{2}$ (Fig. 1). Addition of $\mathrm{Ca}$ as $\mathrm{Ca}\left(\mathrm{NO}_{3}\right)_{2}$ increased the adsorptive capacity of bentonite at low pH (5-6), while higher concentration of $\mathrm{NO}_{3}$ due to the addition of calcium nitrate as $\mathrm{N}$ source resulted in increased adsorption of $\mathrm{NO}_{3}$ at bentonite clay surfaces ${ }^{[39]}$. The process can be further explained by Ca hydrolysis, which resulted into formation of less soluble $\mathrm{Ca}(\mathrm{OH})_{2}$, releasing $\mathrm{more}^{+}$ions, thus acidifying the media (Eq. 1). Under low pH, the anion exchange capacity of bentonites in significantly increased which offers more positive sites to attract $\mathrm{NO}_{3}$ on its surface (Eq. 2), which increased the retention of $\mathrm{NO} 3$ ions on soil colloids due to adsorption phenomenon (Eq. 3). This ultimately reduced $\mathrm{NO}_{3}$ leaching from sandy soil and showed lower $\mathrm{NO} 3$ concentrations in leachate. The entire process can be explained as follows, where $\mathrm{A}$ is dissociated anion and $\mathrm{X}$ is the soil colloidal surface

$\mathrm{Ca}^{2+}+\mathrm{H}_{2} \mathrm{O} \rightleftharpoons \mathrm{Ca}(\mathrm{OH})_{2}+2 \mathrm{H}^{+}$Eq. 1

$\mathrm{X}+\mathrm{H}^{+} \rightleftharpoons \mathrm{X}^{+}+\mathrm{HA} \quad$ Eq. 2

$\mathrm{X}^{+}+\mathrm{NO}_{3}^{-} \rightleftharpoons \mathrm{XNO}_{3}$ Eq. 3

Surface charge of variable charge clays varies with changes in $\mathrm{pH}$ of soil solution, therefore, at low $\mathrm{pH}$, the anion exchange capacity exceeds cation exchange capacities which retain more $\mathrm{NO}_{3}$ on its 
surfaces ${ }^{[14][40]}$, while increasing the mobility of $\mathrm{NH}_{4}$ in such conditions. However, the mobility of both $\mathrm{N}$ forms can be maintained by adjusting the rates of $\mathrm{Ca}\left(\mathrm{NO}_{3}\right)_{2}$ and urea along with bentonite clay under field conditions. The study suggested that bentonite amendment with $\mathrm{Ca}(\mathrm{NO} 3) 2$ as $\mathrm{N}$ sources could effectively mitigate NO3 leaching from sandy soils.

\section{Conclusions}

It is concluded that $\mathrm{N}$ sources and bentonite application were important factors affecting the $\mathrm{NO}_{3}$ leaching from sandy soil. Application of $\mathrm{N}$ sources enhanced $\mathrm{NO}_{3}$ leaching from the sandy soil. The $\mathrm{NO}_{3}$ leaching decreased in the order of $\mathrm{Ca}\left(\mathrm{NO}_{3}\right)_{2}>\mathrm{NH}_{4} \mathrm{Cl}>$ Urea. Bentonite substantially reduced $\mathrm{NO}_{3}$ in the leachate. Urea showed higher $\mathrm{NO}_{3}$ at the later leaching events. Higher contents of $\mathrm{NO}_{3}$ were retained in the soil with $4 \%$ bentonite. Higher $\mathrm{NO}_{3}$ contents were accumulated in the lower part of the soil column after a leaching process. This experiment suggests that bentonite clay chemistry with added $\mathrm{Ca}\left(\mathrm{NO}_{3}\right)_{2}$ provide better understanding of $\mathrm{pH}$ dependent anion exchange capacity to retain higher $\mathrm{NO}_{3}$ concentrations in soil, thereby decreasing $\mathrm{NO}_{3}$ leaching from sandy soil. Further research is suggested to investigate the effects of different clay types on the dynamics of nitrate under field conditions.

\section{Declarations}

\section{Acknowledgement}

Authors appreciate the support of Yunnan Provincial Key Laboratory of Pollution Processes and Management in Plateau Lake Watershed (Project No: 202005AG070105) for funding this work.

\section{Authors Contributions}

Z.H., M.I., R.A.K. led the research study and prepared the manuscript. M.M., C.T., C.Y. analyzed the data and prepared graphs. D.S. facilitated the research. R.A.K. edited the manuscript for technical inputs. All the authors discussed and reviewed the manuscript.

\section{References}

1. Elferink, M, Schierhorn F. Global demand for food is rising. Can we meet it? Harvard Business Review. Harward Business Publishing, Canada (2016).

2. Irshad, M., Waseem, A., Umar, M., Sabir, M.A. Leachability of nitrate from sandy soil using waste amendment. Commun Soil Sci Plant Anal., 45, 680-687 (2014)

3. Kladivko, E.J., Van Scoyoc, G.E., Monke, E.J., Oates, K.M., Pask, W. Pesticides and nutrient movement into subsurface tile drains on s silt loam soil in Indiana. J Environ Qual., 20, 264-270 (1991). 
4. Jacinthe, P.A., Dick, W.A., Brown, L.C. Bioremediation of nitrate-contaminated shallow soils using water table management techniques: Nitrate removal efficiency. Trans ASAE, 42, 1251-1259 (1999).

5. Zeb, S., Waseem, A., Malik, A.H., Mahmood, Q. Water quality assessment of Siran River, Pakistan. Int'l. J. Phys. Sci., 6, 7789 - 7798. (2011)

6. Alexander, R.B., Smith, R.A., Schwarz, G.E. The regional transport of point and non-point source of nitrogen to the Gulf of Mexico. In Proc. Gulf of Mexico Hypoxia Conf. Kenner, L.A. 5-6 Dec 1995. USEPA Publ National Cent for Environ. Publ. and Inf. Washington, D.C. (1995).

7. Kanwar, R.S., Stilenberg, D.E.R., Pfeiffer, D.L., Karlen, T.S., Simpkins, W.W. Transport of nitrate and pesticides to shallow groundwater systems as affected by tillage and crop rotation practices, 270273. In Proc. Natl. Conf. on Agric. Res. to Protect Water Quality (1993).

8. Randall, G.W. Nitrate-N in surface waters as influenced by climatic conditions and agricultural practices. In Proc. Agric. and Hypoxia in the Mississippi Watershed Conf., St. Louis, MO. 14-15 July 1997. Am. Farm Bureau Federation, Park Ridge, IL (1997)

9. Cambardella, C.A., Moorman, T.B., Jaynes, D.B., Parkin, T.B., Karlen, D.L. Water quality in Walnut Creek watershed: Nitrate nitrogen in soils, subsurface drainage water and shallow groundwater. $J$ Environ Qual., 28, 25-34 (1999)

10. Kross, B.C., Hallberg, GR., Bruner, R., Cherryholmes, K., Johnson, K.J. The nitrate contamination of private well water in lowa. Am. J. Public Health, 83, 270-272 (1993).

11. Bibi, S., Saifullah, Naeem, A., Dahlawi, S. Environmental Impacts of Nitrogen Use in Agriculture, Nitrate Leaching and Mitigation Strategies. Hakeem et al. (eds.), Soil Science: Agricultural and Environmental Prospectives, Springer International Publishing Switzerland (2016). https://doi.org/10.1007/978-3-319-34451-5_6

12. Hallaq, A.H.A. The impact of soil texture on nitrates leaching into groundwater in the North Governorate,Gaza Strip. J. Social Sci., 38(2), 1-37 (2010).

13. Hatfield, J.L., Cambardella, C.A. Nutrient management in cropping systems. In J. McFarland and M. Sanderson (ed.) Integrated management of land application of animal waste. (In press.). Am. Soc. of Agric. Eng., St. Joseph, MI (2001).

14. Sirivastava, A., Singh, P.K. Adsorption of Nitrate from Ground Water using Indian Bentonite: Fixed Bed Column Study. Int'I J. Eng. Res. Technol. (IJERT), 6(5), 390-394 (2017).

15. Bentahar, S. Dnik, A., Khomri, M.E., Messaoudi, N.e., Mohammad, A.D., Noureddine, E., Lacherai, A. Removal of a cationic dye from aqueous solution by natural clay. J. Groundw. Sustain. Devel,. 6, 255-262 (2018). https://doi.org/10.1016/j.gsd.2018.02.002

16. De Castro, M.L.F.A., Abad, M.L.B., Sumalinog, D.A.G., Abarca, R.R.M., Paoprasert, P., de Luna, M.D.G. Adsorption of Methylene Blue dye and $\mathrm{Cu}(\mathrm{II})$ ions on EDTA-modified bentonite: Isotherm, kinetic and thermodynamic studies. J. Sustain. Environ. Res., 28, 197-205 (2018). https://doi.org/10.1016/j.serj.2018.04.001

17. Lopez-Fernandez, M., Vilchez-Vargas, R., Jroundi, F., Boon, N., Pieper, D., Merroun, M.L., 2018. Microbial community changes induced by uranyl nitrate in bentonite clay microcosms. Appl. Clay 
Sci., 160, 206-216 (2018). https://doi.org/10.1016/j.clay.2017.12.034

18. Hall, D. J. M., Jones, H.R., Crabtree, W.L., Daniels, T.L. Claying and deep ripping can increase crop yields and profits on water repellent sands with marginal fertility in southern Western Australia. $J$. Aust. J. Soil Res. 48, 178-187 (2010). https://doi.org/10.1071/SR09078

19. Mi, J., Gregorich, E.G. Xu, S., McLaughlin, N.B., Liu, J. Effect of bentonite as a soil amendment on field water-holding capacity, and millet photosynthesis and grain quality. Scientific Reports, 10, 18282 (2020). https://doi.org/10.1038/s41598-020-75350-9

20. Czaban, J., Siebielec, G. Effects of Bentonite on Sandy Soil Chemistry in a Long-Term Plot Experiment (II); Effect on pH, CEC, and Macro- and Micronutrients. Pol. J. Environ. Stud., 22(6), 16691676 (2013).

21. Tahir, S., Marschner, P. Clay Addition to Sandy Soil Reduces Nutrient Leaching-Effect of Clay Concentration and Ped Size. Commun. Soil Sci. Plant Anal. 48(15), 1813-1821 (2017). https://doi.org/10.1080/00103624.2017.1395454

22. Shi, W., Ju, Y., Bian, R., Li, L., Joseph, S., Mitchell, R.G., Munroe, P., Taherymoosavi, S., Pan, G. Biochar bound urea boosts plant growth and reduces nitrogen leaching. Sci. Tot. Environ. 701, 134424 (2020). https://doi.org/10.1016/j.scitotenv.2019.134424

23. Richard, L.A. Diagnosis and improvement of saline and alkali soils (USDA Handbook 60) Washington, DC: USDA (1954)

24. Norman, R.J., Stucki, J.W. The determination of nitrate and nitrite in soil extracts by ultraviolet spectrophotometry. Soil Sci Soc Am., 45, 347-353 (1981).

25. SAS, 1999. StatView reference, third edition, SAS Institute Inc., Cary, NC, USA.

26. Zhou, J.B., Xi, J.G., Chen, Z.J., Li, S.X. Leaching and transformation of nitrogen fertilizers in soil after application of $\mathrm{N}$ with irrigation: A soil column method. Pedosphere, 16(2), 245-252 (2006).

27. De Boer, H.C., Deru, J.G.C., Hoekstra, N.J., Van Eekeren, N. Strategic timing of nitrogen fertilization to increase root biomass and nitrogen-use efficiency of Lolium perenne L. Plant and Soil, 407, 81-90 (2016).

28. Harty, M.A., Forrestal, P.J., Watson, C.J., McGeough, K.L., Carolan, R., Elliot, C., Krol, D.J., Laughlin, R.J., Richards, K.G., Lanigan, G.J. Reducing nitrous oxide emissions by changing N fertilizer use from calcium ammonium nitrate (CAN) to urea based formulations. Sci. Tot. Environ., 563-564, 576-586 (2016)

29. De Boer, H.C. Nitrate leaching from liquid cattle manure compared to synthetic fertilizer applied to grassland or silage maize in the Netherlands. Wageningen Livestock Research Wageningen, October (2017).

30. Zhang, Y.M., Chen, D.L., Zhang, J.B., Edis, R., Hu, C.S., Zhu, A.N. Ammonia volatilization and denitrification losses from an irrigated maize-wheat rotation field in the North China Plain. Pedosphere, 14(4), 533-540 (2004).

31. Zhang, H., Chen, W., Zhao, B., Phillips, L.A., Zhou, Y., Lapen, D.R., Liu, J. Sandy soils amended with bentonite induced changes in soil microbiota and fungistasis in maize fields. Applied Soil Ecology, 
146, (2020). https://doi.org/10.1016/j.apsoil.2019.103378

32. Churchman, G.J. Noble, A., Bailey, G., Chittleborough, D. Harper, R. Clay addition and redistribution to enhance carbon sequestration in soils Soil Carbon, Springer, Cham. 327-335 (2014).

33. Satje, A., Nelson, P.N. Bentonite treatments can improve the nutrient and water holding capacity of sugarcane soils in the wet tropics. Proceed Austr Soc Sugarcane Technol. 31, 166-176 (2009).

34. Ma, R.H.Y., Zong, T., Lu, S.G. Reducing bioavailability and leachability of copper in soils using coal fly ash, apatite, and bentonite. Commun Soil Sci Plant Anal., 43(15), 2004-2017 (2012).

35. Suzuki, S., Noble, A.D., Ruaysoongnern, S., Chinabut, N. Improvement in water-holding capacity and structural stability of a sandy soil in northeast Thailand. Arid Land Res Manage., 21, 37-49 (2007).

36. Liu, X., Liao, J., Song, H. et al. A Biochar-Based Route for Environmentally Friendly Controlled Release of Nitrogen: Urea-Loaded Biochar and Bentonite Composite. Sci, Rep., 9, 9548 (2019). https://doi.org/10.1038/s41598-019-46065-3

37. Wang, F.L., Alva, A.K. Ammonium adsorption and desorption in sandy soils. Soil Sci. Soc. Am. J., 64, 1669-1674 (2000).

38. Wang, Y., Zhang, Y.P. Ammonium adsorption in a Eum-Orthic Anthrosol at different solution / soil ratios and temperature. Pedosphere, 14(2), 253-257 (2004).

39. Ouakouak, A., Youcef, L., Achour, S., Hamdi, N. Kinetics and equilibrium studies of nitrates adsorption onto natural Bentonite. Conference paper, Colloque International Sciences \& Techniques de l'Eau \& Environnement (STEE) (2018)

40. Sollins, P., Robertson, G.P., Uehara, G. Nutrient Mobility in Variable- and Permanent-Charge Soils. Biogeochemistry. 6(3), 181-199 (1988).

\section{Figures}




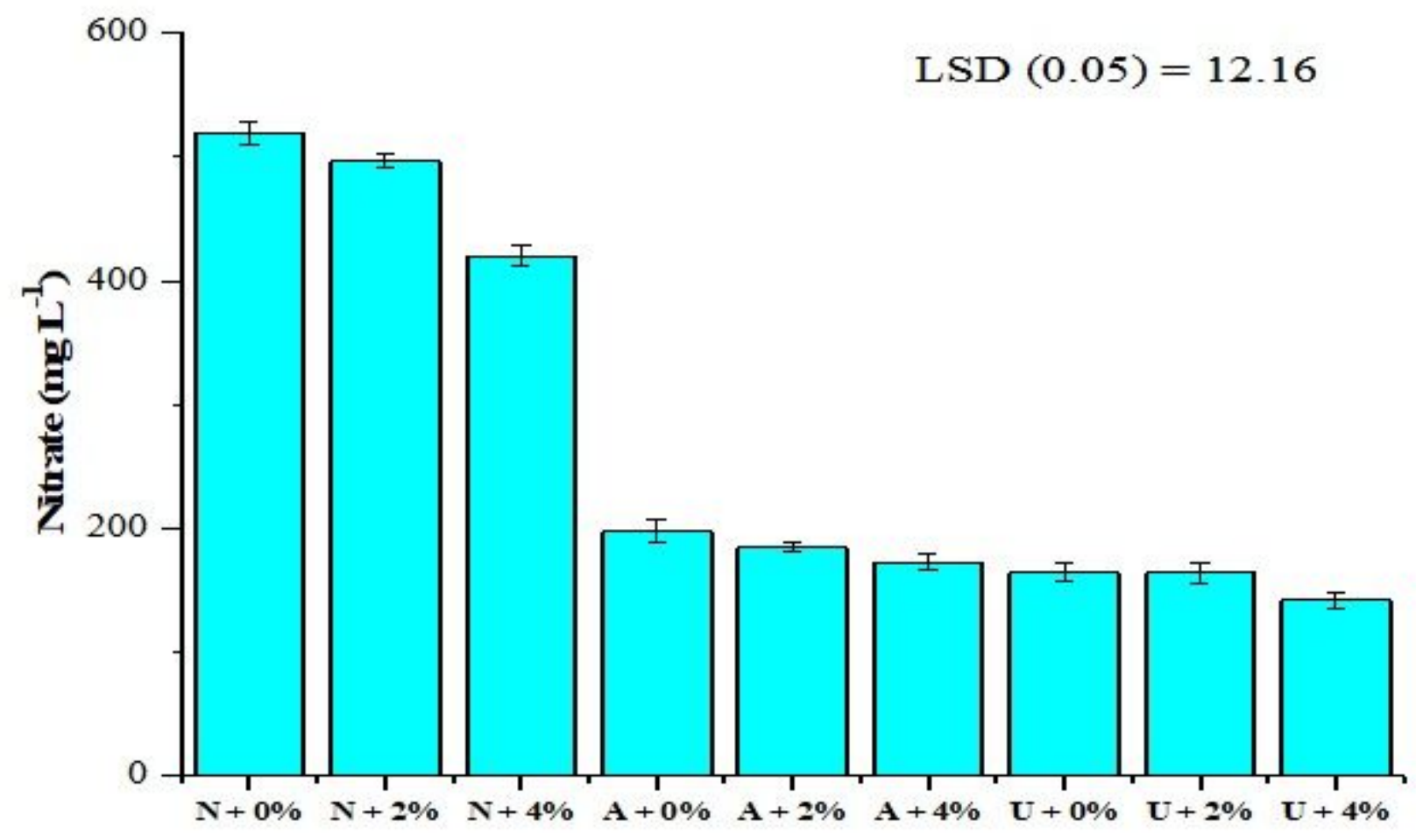

Figure 1

Average leachate nitrate from bentonite treated sandy soil (from day 1 to day 10 ). N, A and U indicate $\mathrm{Ca}(\mathrm{NO} 3) 2, \mathrm{NH} 4 \mathrm{Cl}$ and $\mathrm{CO}(\mathrm{NH} 2) 2$, respectively. Bentonite clay was applied at the rate of $0 \%, 2 \%$ and $4 \%$. 

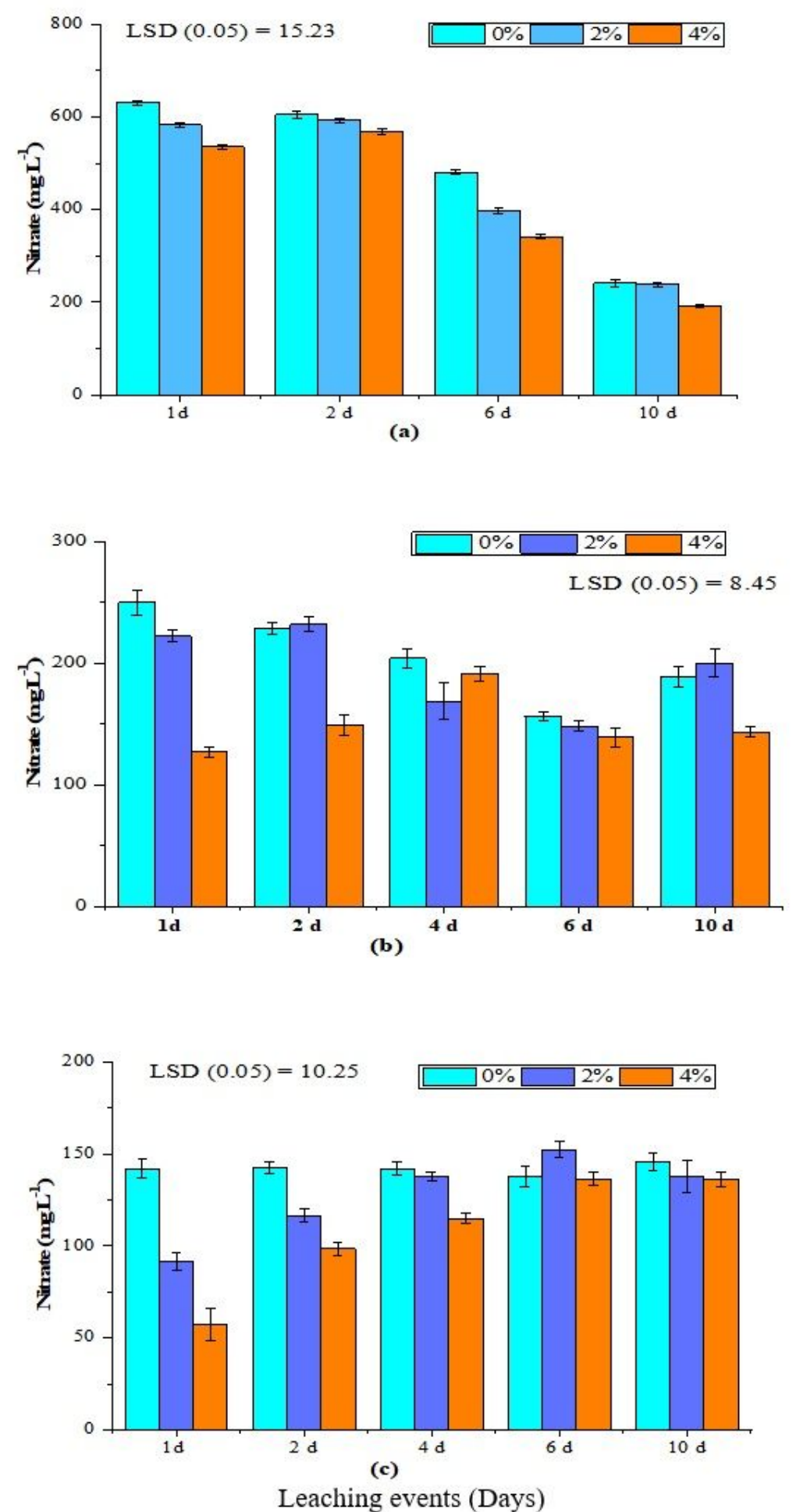

Figure 2

Nitrate leaching in bentonite amended sandy soil using $\mathrm{Ca}(\mathrm{NO} 3) 2(\mathrm{a}), \mathrm{NH} 4 \mathrm{Cl}(\mathrm{b})$, and $\mathrm{CO}(\mathrm{NH} 2) 2$ (c) during five leaching events 


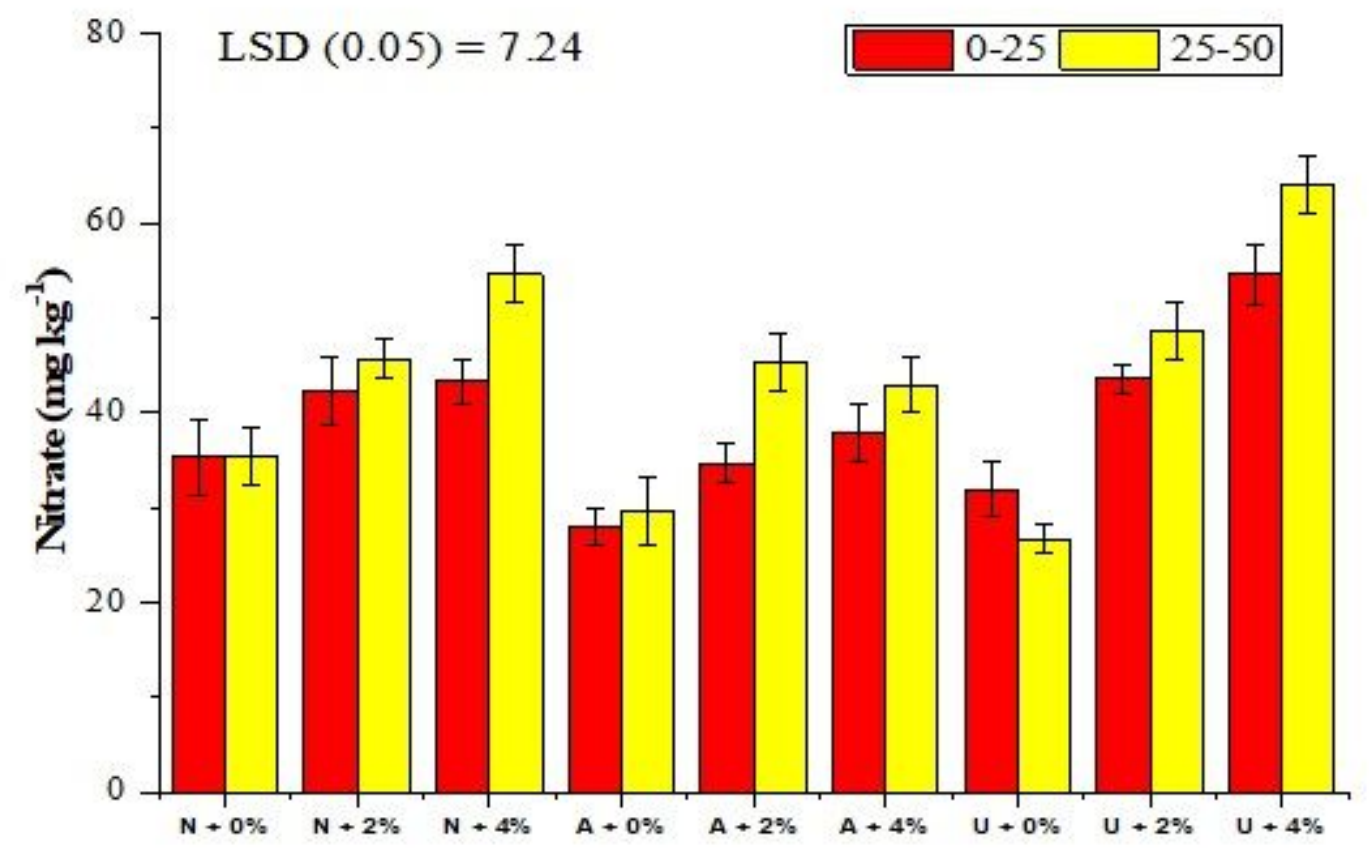

Figure 3

Residual nitrate concentrations found in soil after leaching events

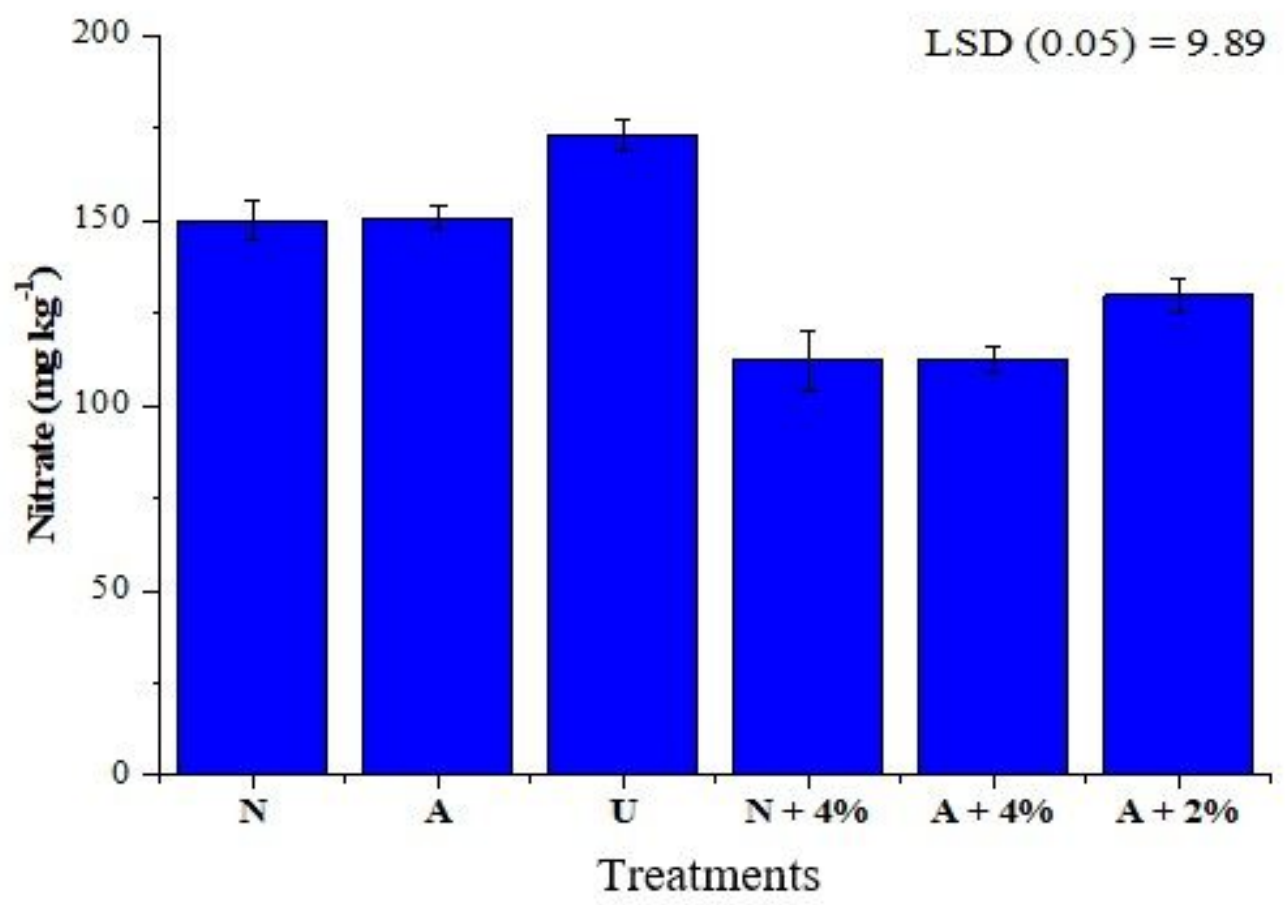

Figure 4 
Nitrate concentration in $4 \%$ bentonite clay mixed sandy soil after discrete incubation with $\mathrm{Ca}(\mathrm{NO}) 2(\mathrm{~N})$, $\mathrm{NH} 4 \mathrm{Cl}(\mathrm{A})$ and $\mathrm{CO}(\mathrm{NH} 2) 2(\mathrm{U})$ 